\title{
Social Trust and Dynamics of Capitalist Economies in the Context of Clashing Managerial Factors with Risks and Severe Turbulence: A Conceptual Inquiry
}

\author{
Aurel Burciu, Rozalia Kicsi and Ionel Bostan *(D) \\ Faculty of Economics and Public Administration, "Ştefan cel Mare" University, 720229 Suceava, Romania; \\ aurelb@usv.ro (A.B.); rozaliak@seap.usv.ro (R.K.) \\ * Correspondence: ionel_bostan@yahoo.com or ionel.bostan@fdsa.usv.ro; Tel.: +40-230-216-147
}

Received: 14 September 2020; Accepted: 21 October 2020; Published: 22 October 2020

\begin{abstract}
Nowadays, in the context of a complex fragility that radically transforms the economic habitat, the cyclical evolution of the economy is governed by new rules and constraints that transcend the economic area and increasingly interfere with the socio-cultural features of life. In this context, the aim of this paper is to outline the conceptual domain of a new insight into the relationship between social and economic dimensions of life by summarizing and integrating two of the main groundbreaking and inspirational streams of thought-social trust and economic dynamics. To do so, we developed theoretical syntheses of the most important contributions documenting the nature of trust and business cycle; then, the much more recent "niche" of the influence between them was placed under conceptual discussion. One of the more significant findings to emerge from this study is that the nature of the relationship between social trust and economic dynamics is still minimally explored and understood, and the research conducted thus far is mainly positioned in a macroeconomic perspective, combining quantitative and qualitative approaches that still leave many questions unanswered. However, the lack of a deep understanding of these influences launches new challenges for theoretical developments and creates the framework for an integrative understanding. These new insights can support more rigorous studies whose results could be of utmost importance for business organizations in addressing the problem of business sustainability, but also for economic decision-makers. At the macro level, economic crises are influencing the income distribution and are expected to exacerbate poverty, thus affecting progress towards Sustainable Development Goal 01 (No poverty).
\end{abstract}

Keywords: trust; social capital; turbulence; risk; panic; economic dynamics; sustainability; management

\section{Introduction}

Social trust is a core component of social capital. The interest in this subject transcends the area of sociology and extends in many other disciplines such as economics, business and organization studies, psychology, and philosophy. The economy of impermanence and the current complex fragility create a habitat in which human behavior and economic behavior are governed by other rules and constraints in comparison with few decades ago. In this context, the literature provides fragmented answers to questions about the interferences between the socio-cultural dimensions and the economic dimensions of life. This derives from the subjective nature of social trust, whose dimension is difficult to capture through objective indicators. However, the lack of a deep understanding of these influences launches new challenges for theoretical developments and creates the framework for an integrative understanding. 
Our paper aims to outline the conceptual domain of a new insight into the relationship between social and economic dimensions of life by summarizing and integrating two of the main groundbreaking and inspirational streams of thought-social trust and economic dynamics.

Both the area of knowledge focused on social trust and the area in which the issue of the dynamics of capitalist economies is positioned are mature, and they are built on major contributions. As such an integrative approach requires an understanding of the essence/nature of social trust on the one hand, and of the evolutionary patterns of capitalist economies on the other hand, we posed the following research questions: (1) What is the nature of social trust as a core element of social capital? (2) What are the patterns of evolution of capitalist economies? (3) How do distrust, fear, and panic influence the amplitude of the economic cycles in the current chaotic environment?

To answer these questions, we reviewed the core literature, identified the main themes, and selected the themes of interest for this research. Then, a conceptual discussion was developed on the basis of these themes.

The remainder of the paper is organized as follows. The next section presents the research design, followed by theoretical synthesis. The paper continues with discussions and implications of the study and concludes with future research conclusions and directions.

This paper extends the area of knowledge by summarizing and integrating the conceptual paradigm of social trust and the dynamics of capitalist economies. Subsequently, this paper contributes to the literature by offering an image of the scientific landscape shaped by the concept of social trust; it points out the main directions of research in this area and explores a relatively new scientific niche. Furthermore, the research strategy is developed on the basis of a bibliometric analysis performed with a specialized software.

These new insights can support more rigorous studies whose results could be of utmost importance for business organizations in addressing the problem of business sustainability, but also for economic decision-makers. Business organizations, especially Small and Medium Enterprises, are vulnerable to recessions/economic crises and, often, when designing their countercyclical strategies, rely predominantly on economic and financial indicators. There is still a big question mark regarding the interest of companies towards social factors, which, together with other factors (economic, political, technological, etc.), shape the environment in which they operate and want to gain profit and a better position on the market. At the macro level, economic crises are influencing the income distribution and are expected to exacerbate poverty, thus affecting progress towards Sustainable Development Goal 01 (no poverty).

\section{Research Design}

Outlining the conceptual domain of a new insight into the relationship between social and economic dimensions of life required a mixed research approach that demanded the following phases: synthesis preparation, synthesis development and refinement, and conceptual discussion.

Synthesis preparation consisted of the exploration of the thematic area that has social trust as a central element and of establishing the main research directions through a bibliometric analysis. Then, a review of the main body of the literature was performed and the relevant sources for this study were selected.

Synthesis development and refinement involved the examination of theories that explain social trust as an element of social capital (from the perspective of its economic valences), as well as significant contributions explaining the pattern of the dynamics of capitalist economies.

Conceptual discussion employed a conceptual advancement, considering a new level of interpretation of the influences between social trust and business cycle.

The interest in the issue of social trust, having its primary vein in the field of sociology, has brought over time essential topics into the horizon of reflection that have shaped a vast theoretical corpus, materialized by scientific articles in academic journals, books, business magazines, reports of international organizations, non-profit organizations, etc. To shape the research context, we selected 
the most relevant contributions that acquired intellectual dominance in this broad thematic area. The scientific articles were identified and selected from the Web of Science Core Collection, where a preliminary search on the topic "social trust" was conducted; then, the results of this search were processed and analyzed to identify the main thematic areas. The search strategy is outlined in Figure 1.

- Data base: Web of Science Core Collection

- Mode: Advanced Search

- Document types: all
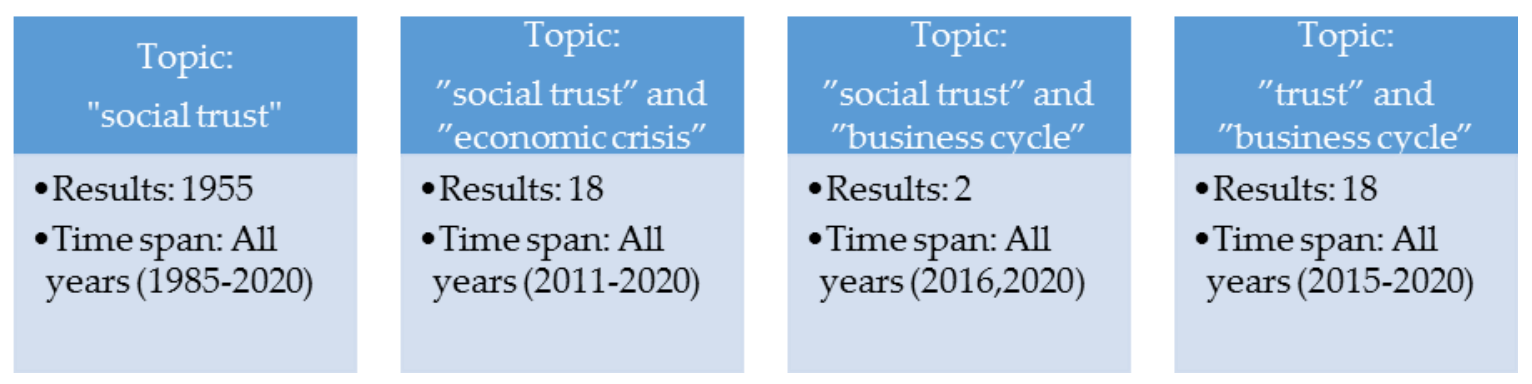

Figure 1. Preliminary search strategy in Web of Science Core Collection.

For the topic "social trust", the search revealed 1955 results (articles, proceedings papers, book chapters, reviews, etc.), covering the period of 1985-2020. Figure 2 illustrates the dynamics and profile of scientific research at the international level on the topic of social trust during the period of 1985-2020.
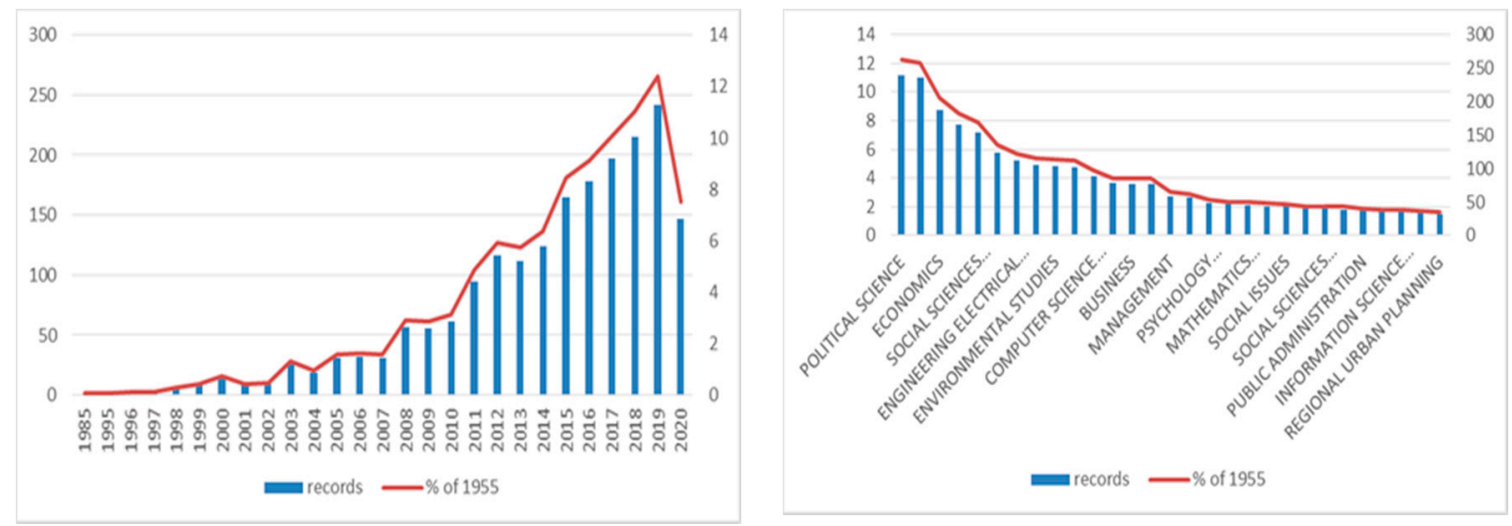

Figure 2. International research profile during the period of 1985-2020. Source: Developed by authors on Web of Science database, http://apps.webofknowledge.com.

During this period, the thematic areas in which scientific production stood out were diversified; thus, if studies on the selected topic were carried out mainly in categories such as political science and social science in the 1990s and early 2000s, the research flow now covers over 100 thematic areas, with interest becoming obvious in fields other than traditional ones, namely, economics, business, and management, among others.

In order to explore the main research directions in the thematic register covered by the social trust, we performed a frequency analysis of the keywords in the titles/abstracts of the articles indexed in the Web of Science database using VOSviewer. The minimum number of occurrences of a keyword was 5; of the 6292 keywords, 426 meet the threshold. For each of the 526 keywords, we calculated the total strength of the co-occurrence links with other keywords. The keywords with the greatest total link strength were selected. 
In Figure 3a, the size of the circles represents the appearance of the keywords; thus, the larger the circles, the more keywords were selected in the publications on the analyzed topic. The distance between two keywords demonstrates the relative connection and similarity between topics. Circles in the same cluster suggest similar topics in selected publications. Thus, Figure 3a reveals the existence of seven significant clusters correlated with the scientific research on the analyzed issue. In the largest cluster (red-1; 124 items), keywords such as attitudes, risk, knowledge, management, hazards, public trust, power, decision-making, economics, and sustainability are related to the topic "social trust". The next cluster (green-2; 110 items) was shaped by connections between keywords such as income, inequality, education, subjective well-being, political economy, welfare state, development, and financial crisis, which focused on the main field of "social capital". In the third cluster (blue-3; 67 items), keywords such as growth, performance, economic growth, uncertainty, economic, development, business, and corporate governance and are linked to the topic "institutions". The fourth cluster (light green - 4; 63 items) includes keywords such as states, politics, eroded trust, discrimination, justice, and social identity that are concentrated around the topic of "generalized trust". The following cluster (purple-5; 57 items) combines keywords such as government, political trust, civil society, engagement, organizations, economic crisis, and trust with the topic "participation". The sixth cluster (light blue-6; 54 items) reveals connections between keywords such as institutional trust, interpersonal trust, trustworthiness, public goods, human capital, and sustainable development and the topic "behavior". In the last cluster (orange-7; 50 items), the topic "networks" is interlinked with keywords such as social networks, distrust, trust management, social influence, implicit trust, and trust network.

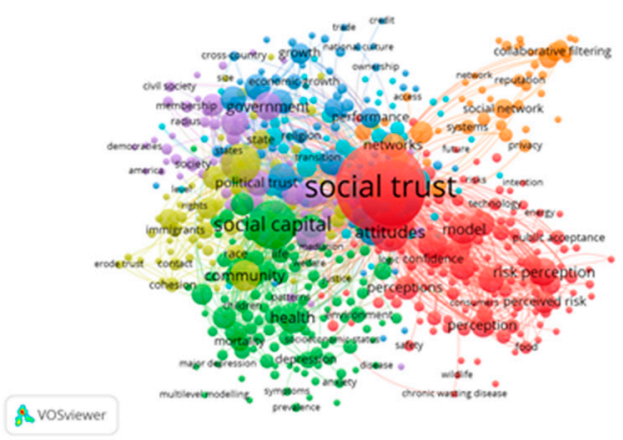

(a)

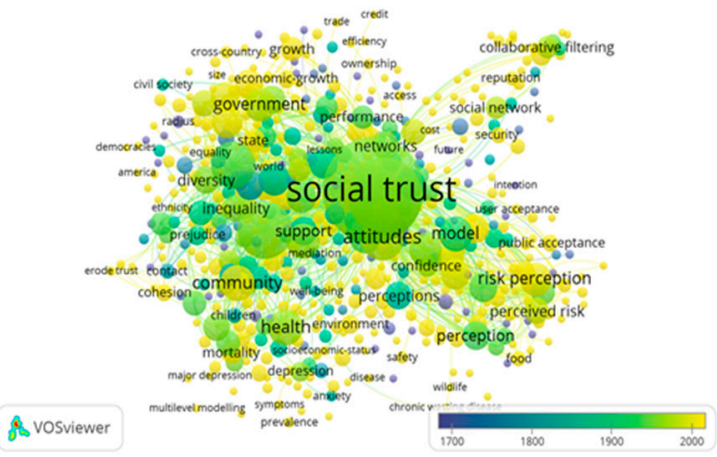

(b)

Figure 3. Co-occurrence keyword network (1985-2020). Note: (a) Co-keyword network visualization (occurrences); (b) co-keyword overlay visualization (occurrences and average publication year scores). Source: Developed by authors with VOSviewer.

Figure $3 \mathrm{~b}$ reflects the distribution of the appearance of keywords in the selected publications over time. A more conclusive image on links and total links strength information of the main occurrence keywords is shown in Table 1. 
Table 1. The links and total links strength of selected occurrence keywords.

\begin{tabular}{cccccc}
\hline Keywords & Cluster & Occurrences & Links & Total Link Strength & Average Publication Year \\
\hline Social trust & 1 & 848 & 509 & 4924 & 1938 \\
Trust & 1 & 453 & 472 & 2561 & 1960 \\
Social capital & 2 & 249 & 341 & 1464 & 1940 \\
Generalized trust & 4 & 166 & 292 & 1254 & 1930 \\
Attitudes & 1 & 154 & 314 & 1106 & 1961 \\
Health & 2 & 100 & 222 & 622 & 1953 \\
Community & 4 & 100 & 230 & 706 & 1993 \\
Participation & 5 & 95 & 274 & 717 & 1950 \\
Determinants & 3 & 91 & 264 & 707 & 1926 \\
Risk & 1 & 90 & 229 & 604 & 1946 \\
Risk perception & 1 & 87 & 158 & 683 & 1989 \\
Government & 5 & 84 & 191 & 632 & 1965 \\
Economic crisis & 5 & 6 & 42 & 57 & 1727 \\
Business & 3 & 7 & 26 & 40 & \\
\hline
\end{tabular}

Source: Developed by authors with VOSviewer.

In the table above, a link is a co-occuring connection between two keywords. Each link has a strength expressed by a positive numerical value; the higher this value, the stronger the link. The strength of a link may indicate, among other things, the number of publications in which two terms occur together (in the case of co-occurrence links). As can be seen, social trust and business cycle are quite a new research hotspot in the scientific landscape.

The conclusion that led this preliminary analysis is that the interest in investigating the relationship between social trust and economic crisis is more visible in scientific articles after 2011, but addressing the influences between social trust and business cycle is proving to be a barely open niche. The search in Web of Science Core Collection generated very few results in this direction, and from these results, we selected those that more clearly address the issue under review.

Some references sent us to additional sources, outside the original purpose of the research; these sources were identified online. For the most cases, such references were business magazines, books, and reports of international organizations; they were reviewed and selected according to their relevance and contribution to the paper.

\section{Theory Synthesis: Social Trust and Economic Dynamics}

\subsection{Trust-The Heartland of Social Capital}

It is well known that the outbreak of modern sociology is placed somewhere around 1900, especially after the publication of M. Weber's influential work, The Protestant Ethics and the Spirit of Capitalism [1]. Less than a decade after the publication of this work, in 1912, Durkheim [2] published a reference work on the influence of religion upon social life. Obviously, religion exerted, and still continues to exert, a major influence on social life, on the relationship between the individual and the group to which one belongs. Nevertheless, Weber and other authors in the beginnings of modern sociology were wrong when they attributed to religion a direct influence on the economic performance of certain groups or nations. For example, in cases such as Japan, South Korea, or China, economic performance is completely dissociated from religion. Moreover, Weber and Durkheim do not analyze the significance of trust in interpersonal relationships, but argue that some virtues such as honesty and work ethic can explain the economic performance of some social groups. Human virtues such as honesty, temperance, and fulfillment of duty do not necessarily establish a climate of interpersonal trust between individuals and/or institutions. Various other factors influence the values that people believe in and the contexts that could strengthen or weaken trust. However, the study of the direct relationship between trust and the economic life of social groups, organizations, or individuals is more recent and lies on the border between sociology and economics. 
As will be argued later, starting with the cycles of Kondratieff [3], there is a growing body of literature attempting to explain the cyclical evolution of capitalist economies, but these studies are focused mainly on economic causes of the cycles. The evaluation of trust and its potential role in the economic performance of different kinds of groups became a topic of reflection in sociology and, later, economics.

As far as it is known, only in Keynes's thoughts can we find a deeper analysis of the influence of social trust and the behavior of groups on the evolution of economic life, with some explicit reference to the dynamics of capitalist economies. Keynes is also known for the phrase "animal spirits", a picturesque label he applies to an essential ingredient of human behavior, namely, confidence. He argues that, beyond the instability caused by speculation, "there is the instability due to the characteristic of human nature that a large proportion of our positive activities depend on spontaneous optimism rather than on a mathematical expectation, whether moral or hedonistic or economic" [4]. A better-supported study of the relationship between confidence, in the sense of Keynes's thought, and the dynamics of capitalist economies is found in Padua's work, The Economy of Trust (noting that there are some differences between confidence and trust) [5].

Trust was defined from various lenses, namely, psychological; sociological; philosophical; and, more recently, economic. In general, trust means the expectation that a person has from another person, group, or institution that they/it will manifest an ethical behavior now or in the future that is correct and oriented towards the common good. Such honest social behavior is based on a set of core values promoted through the education received from the family, school, and social environment. Put another way, there is a tendency to trust people, groups, or institutions that exhibit predictable behaviors that are based on values close to or similar to ours.

Beginning with the 1950s of the last century, the topic of trust has held the attention of psychologists [6], and a gradual transition from the vision of trust in interpersonal relationships to the vision of trust in the performance of organizations has taken place. A little later, Rotter proposed a scale for measuring the degree of trust of individuals in various institutions (Interpersonal Trust Scale - ITP) [7]. Near the 1980s, under the influence of the institutional economics, Luhmann made a distinction between trust in people and trust in a system [8]. Subsequently, a clearer distinction between interpersonal trust and the trust of individuals in institutions, corporations, banks, etc. was drawn [9]. It is worth noting that after the 1980s, the area of influence exerted by trust on modern society greatly expanded. Studies by sociologists such as Putnam and Fukuyama opened new directions in understanding the role of social trust in economic life and, implicitly, in economic dynamics.

According to Putnam, social capital is shaped by trust, social competition, and the relationships built jointly by members of a community [10]. Authors such as Hofstede [11], Inglehart [12], or Huntington [13] pertinently assert a direct relationship between a nation's culture and its economic performance. From this point of view, the core values in the spirit of which individuals are educated becomes central elements of a culture. Despite the extension of research on this topic, we still do not know what kind of relationship exists between culture and political institutions in a country, and also we do not know what the crucial factor of the relationship is with the other. There is no coincidence that we return to the influential works of Inglehart, Huntington, and others when we explore certain indices used to globally measure values and prosperity. In some of the groundbreaking works of Fukuyama, both the concept of social capital and the influence of social trust on the economic performance of some countries are explored [14]. In a study published in 1995, Fukuyama emphasizes a clear relationship between trust and the performance of companies and others types of organizations in certain countries (e.g., USA, Japan, South Korea, China, Germany, France, Italy, England) [15]. We believe that Fukuyama's study of trust is the best descriptive argument developed by a sociologist regarding the influence of trust on the economic behavior of individuals. However, it is difficult to say how institutions and companies in a country should act to enhance the level of trust in society at a given time. This conclusion is of particular significance, especially when global recessions or economic crises are foreseen (as seen in the global economy in the first part of 2020). It is obvious that governments 
have a major and direct role in building and/or strengthening social trust, as Herreros notes [16]. However, we must take into account the way in which millions of people react to certain actions or decisions of governments in order to understand the evolution of social trust and its relationship with prosperity in the major countries of the world. Each individual has certain "cultural roots" that influence his or her behavior in relation to other members of the group [15]. Therefore, although there is a growing body of literature documenting trust and social capital, many issues remain unclear or even contradictory when trying to link the evolution of prosperity with some level of trust in society.

Some sociologists, including Putnam, point out that the 1990s brought a decline in trust and a deterioration of other elements of social capital in the United States and other Western countries [17]. The global crisis of 2007 was also accompanied by a deterioration in the structure of social capital in the main countries of the world. However, as it will be discussed later, the elements of social capital can be quickly rebuilt when governments and citizens react and change their economic behavior. Moreover, some sociologists consider that the study of social capital would have limited relevance for the creation of wealth and that there are too many dimensions or components of the concept, which limits its application [18]. On the contrary, we believe that all components of social capital should remain of interest for future analysis and research in an attempt to develop a deeper understanding of the cyclical evolution of capitalist economies in terms of how economic crises or recessions can be managed, as well as of the countercyclical strategies that companies should apply.

The idea that social trust has a significant economic value is no longer a new issue-it is a topic that comes back to the horizon of theoretical reflection mainly due to the current context. Although per definitionem its vein comes from the sociological area, the study of the connections between social trust and the evolutions/transformations that shape economic systems have been refined and opened to diverse ideological interpretations. Thus, from the last decades of the 20th century, at the confluence of economic, technological, and geopolitical mega tendencies, the interest in the issue of trust in the new modernity began to shape its own physiognomy and a clearer status.

In a gold standard paper originally published in 1990, Anthony Giddens sets out a theoretical construction that incorporates his vision of modernity and the substance of trust in the context of modernity. In the modernity described by Giddens (1990) [19], daily life is organized by disintegrated institutions that link local practices with globalized social relations. Modernity has revealed a new risk profile. Thus, on the one hand, among the prominent features are the globalization of risks, both in the sense of intensity and in the sense of expanding the number of related events that affect an increasing part of the population. On the other hand, there are risks arising from the created environment or what he calls the "socialized nature", as a result of the infusion of human knowledge into the material environment and the alteration of the relationship between human beings and the physical environment. In this context, Giddens [19] proposes the concept of ontological security as the main source of trust-an expression of the confidence that most people have in continuity of their identity and in the steadiness of the social and material environments of action that surround them. Ontological security, a phenomenon that is more emotional than rational in Giddens's vision, is built on a sense of the safety of people and things, being central to the notion of trust.

The concept of social capital is closely linked to the hypostases of trust. In this direction, Fukuyama's contribution appears as a major source of exploration of the economic valences of social trust. The message conveyed by trust is that the social virtues and the creation of prosperity is concise - the level of trust inherent in society, as a pervasive cultural characteristic, conditions not only a nation's ability to compete, but also its well-being [15]. Therefore, social capital becomes the crucible of trust and the critical element for the health of an economy $[14,20]$. Fukuyama's vision articulates on a body of arguments previously constructed by James Coleman; thus, social capital is the ability of people to work together for common purposes in groups or organizations [21].

The degree to which communities share common norms and values, as well as their ability to ensure the primacy of group interests, significantly influence this ability; among these values, trust is 
crucial and has a significant economic value. This perspective is later refined, in a deep radiography of Italian and American society, by Robert Putnam [10,17].

In post-industrial economies and societies, technological development seems to have eroded the importance of organizational hierarchies and translated the emphasis on networks, considered more apt to respond to the dynamics of the environment of action. Economic rationality per se, supported by the contract and the law that governs it, is often credited as having absolute valences in ensuring economic well-being and stability. Fukuyama [15] builds a series of counterarguments to this approach, evoking the example of high-trust societies, such as Japan, in which networks such as the ones mentioned above emerged long before the information revolution expanded. The conclusion drowned by Fukuyama is that the degree of trust and the social capital existing in the society significantly influence the ability of companies to move from large hierarchies to flexible networks.

With reference to issues already discussed, there are several in-depth studies on the importance of trust and values in relation to the economic performance of large social groups such as countries/nations. In contrast, the study of the relationship between trust and/or values and the performance of a company (thus, from a microeconomic perspective) is less commonly encountered in fields such as economics, sociology, psychology, and management. This is because at the microeconomic level there are millions of entities in the global economy, each with their own history, their own hierarchical organization, their own organizational culture, etc. [22]. The equivalent of what it is called "social capital" at a country/nation level is, in fact, what it is called "organizational culture" at a firm/company level. An interesting but puzzling study connecting macro- and microeconomic perspectives and attempting to provide a holistic explanation of economic behavior and wealth creation by social groups is that of Max Weber [1]. Weber's view of education and work ethics has today become more relevant than ever in the past. This is because only through education in the family and school can a set of positive values be developed to the individual level, and around these values, a globalized society can be built. Such a globalized society is in itself a huge technical, social, and economic network in which the interdependence of millions of individuals and organizations offer advantages but also disadvantages in creating common prosperity.

Unfortunately, however, in today's atomized society, as Padua [5] points out, a diminution of all traditional forms of trust-be it institutional trust (individual-institution), interpersonal trust (individual-individual), or systemic trust (individuals-transnational organizations responsible for carrying out processes, such as economic ones)—is obvious. Assuming the analysis of how the various assumptions of trust are reflected in Keynes's work, Padua considers that Keynesian trust is institutional and systemic, representing the main fabric of a country's social capital [5]. According to the perspectives discussed above, Padua argues that trust has a very high social relevance as a generator of economic action.

Ontological security is replaced by ontological insecurity when a reduction or even a collapse of trust occurs within a network of interdependence. Understood and described as a confrontation/clash with the fragility of complexity, panic thus becomes the expression of this ontological insecurity. In the terms in which Giddens operates, it could be said that panic reflects an awareness of the loss of confidence in economic and social environments of action; herein also comes the lack of predictability, because what is predictable inspires trust. The concept of ontological security advanced by Giddens significantly inspired Keith Tester, who, in the work Panic [23], using mainly sociological tools, builds the discussion about trust around the idea of panic. Essentially, panic is the sense of insecurity that arises when the environments of action can no longer be accepted as constant because of the impact of an event perceived as risk or a chaotic social event [23]. Starting from this explanation, Tester formulates the hypothesis of an amplification of panic when, in a network of interdependence, a collapse of trust arises because the network has become inevitable and, therefore, the solution to panic is to strengthen the institutions recognized as guarantors of ontological security.

Economics has firmly adopted the thesis that trust is associated with equality, conceptualized in two dimensions, namely, economic equality and equal opportunities, although the literature dedicated 
to social capital does not yet grant sufficient importance to these dimensions [24,25]. Well-known examples of countries with high levels of confidence where the level of economic equality and equal opportunities are high are the Nordic countries, the Netherlands, and Canada. However, as Rothstein and Uslaner [24] point out, many countries with low scores in terms of social trust and social capital may remain cornered in the so-called social trap; in other words, social trust will remain low because significant social inequalities prevail and, at the same time, public policies that could remedy this situation cannot be implemented due to the considerable lack of trust.

The economic turbulence of the 20th century, but especially the 2008 crisis with its implications on the workforce [26-28], provided a new context for exploring the connections between economic recessions and social trust. All these are of great interest for the managerial factor oriented towards the desired sustainability [29-32]. Examining the topic, a number of studies conducted in recent decades concluded that trust, both institutional and individual, tends to decline when socio-economic conditions deteriorate [33-35]. However, it remains unclear as to whether the deterioration of institutional trust is directly caused by severe economic conditions or is an indirect effect of dissatisfaction with the institutions' response to citizens' needs and demands [36]. At the macroeconomic level, the evidence suggests that socio-economic difficulties negatively correlate with the level of trust.

The issue of social capital and the relationship between it and the economic growth and prosperity of capitalist countries is argued by Robert Putnam and Francis Fukuyama $[10,14,15,17]$. In fact, the concept of social capital is part of the analysis of the cultural specificity of the main countries of the world but from a different point of view. In other words, the social capital of a country offers us another relatively visible "facet" regarding the values around which a national culture oriented to economic performance is built over time. Little is known on how the relationship between culture and political institutions manifests itself and how this relationship is reflected in the economic behavior of large social groups. According to Fukuyama's arguments, trust, values, type of competition, and tendency towards sociability of social groups are the main elements that drive the formation of the social capital in a country/nation. Among all the four components of social capital analyzed by Fukuyama, trust and values in which the members of a social group believe particularly become a catalyst for competition and network of relationships. In all capitalist countries, as Fukuyama argues, social capital that favors economic growth can be developed through a continuum of social norms [13], as follows:

- $\quad$ enforced norms, imposed by the Constitution, laws, contracts, etc.;

- spontaneous norms, which become predominant in the social behavior and the relationship between the individual and the group.

In other words, over time, trust becomes a kind of "social agent" or "lubricant" that makes a group of people (several hundred in a company and/or millions of people in a country) self-administer more effectively compared to other social groups within which there is a state of distrust. Trust means the attitude or expectation that a person has towards the honest, correct attitude or behavior of other individuals. If there is a state of trust between two or more persons, between individuals and institutions, as well as among different institutions of the modern society, then the general economic relations, as well as those based on the contract, will be carried out more efficiently and at lower costs in each type of transaction; therein, entrepreneurial activity will obviously expand [37].

The transition from trust to distrust in the relationship between two individuals, as well as in the relationship among individuals and different institutions, can occur gradually or suddenly when external disturbing factors appear and create a non-predictable context. It is not very well known as to how the state of distrust existing at the level of a social micro-group can gradually turn into a state of fear, but the appearance of the climate of fear is directly associated with the risks and the uncertainty of the new context created among members of a group.

Furthermore, in the sense invoked, panic means a state of generalized fear at the level of a social group, which most often manifests itself through a behavior without rationality. When a state of panic occurs at the level of a local community, region, or even at the national economy level, the consequences 
of this psychological state can have negative influences on economic life, being equivocal to riots or even total social disorder.

The prosperity of a country, as Porter [38,39] argues, is ultimately about improving the microeconomic foundation of the competition among individuals, as well as the competition among companies, involving the rules governing competition, values, and the trust that exists in society.

Further study or analysis of the influence of trust on microeconomic competition remains a subject that has been scarcely explored in the last decades as it is closely connected with the cyclical evolution at the firm level. As it is known, there are few studies that address the business cycle only from a micro-economic perspective, as this topic, in turn, is a significant part of the theory of business organizations.

The central idea of modernization theory is, according to Inglehart and Welzel [40], that economic development generates systematic changes in the social and political areas. On the basis of the research conducted in the World Values Survey and the European Values Survey, the two authors conclude that the emergence of post-industrial societies causes a different set of changes in the motivations and values of individuals in comparison to the transition from the agrarian to the industrial economy. As the development of post-industrial societies and the expansion of the knowledge economy progresses, the focus is shifting from the values of existential security to those of self-expression. This reflects, in the authors' opinion, a polarization between the emphasis on order, economic security, and compliance and the emphasis on self-expression, participation, subjective well-being, trust, tolerance, and concerns about quality of life [12].

The efforts made in recent years at the international level to study and quantify social capital prove the extended recognition, not only in the academy, of the importance this dimension has for other components of economic and social life. However, given its nature, social capital is difficult to capture with objective quantitative instruments, with most of the studies mainly being based on subjective qualitative approaches.

The Legatum Prosperity Index, for example, captures a comprehensive picture of the institutional, economic, and social aspects of prosperity. This index reflects the performance of 167 countries on 65 directions for analysis evaluated through over 290 indicators [41]. The areas considered essential for prosperity are inclusive societies, open economies, and empowered individuals. The most recent report provides an overview of developments in each area described by a number of important pillars. Social capital is one of the pillars on which inclusive societies are based, with personal well-being being better ensured in societies where trust is one of the main shared values. In the assessment of the social capital in the analyzed countries, interpersonal trust, institutional trust, and social networks accumulated $60 \%$ of the final score. Globally, the score for the social capital pillar increased after 2009, being the only pillar in the area of inclusive societies where improvements have been gained during recent years. Thus, during the period of 2009-2019, the most remarkable improvement concerns social networks, followed by institutional trust; the score for interpersonal trust was lowered, which was, moreover, the only negative evolution in the social capital pillar. However, regional analysis reveals divergent developments [41]. For example, in North America, social capital had the greatest decline of all the pillars that characterize the three areas; the conclusions of the study lead to the idea that North American society (with particular reference to the United States) loses in terms of cohesion, mainly due to the tendency to accentuate institutional distrust. Unlike in North America, social capital had a modest decline in Western Europe because, among the 28 analyzed countries, the score for this pillar improved in 9 and deteriorated in 11. Eastern Europe was the second region, after Asia-Pacific, that saw improvements on most of the pillars, although historically the region has had poor performances in terms of social capital. After 2009, 17 of the 23 analyzed countries improved their positions, mainly due to the development and strengthening of social networks. 


\subsection{Patterns of the Dynamics of Capitalist Economies}

The way in which social groups behave remains an open issue that is insufficiently clarified in fields such as sociology, psychology, philosophy, and economics. This is because the dynamics of social groups is an extremely unclear subject, one that is "fuzzy", and cannot be captured and described comprehensively enough by econometric models. However, even descriptive models can be useful in understanding this complex socio-economic phenomenon.

The Great Depression of 1930s raised major questions for the macroeconomic theory of the time. It questioned the very existence of the Western capitalist system [42]. Renowned economists such as Robbins [43] and Galbraith [42] have tried to explain the factors that generate such crises in the evolution of capitalist economies and, in particular, how such periods should be managed by governments, banks, firms, citizens, etc. We cannot predict, as Robbins notes, when a depression or crisis will occur in the evolution of a capitalist economy and how long it will last, as this depends on how humans will act in the first signs of an economic crisis [43].

Thus, classical economists have argued that the prevention and management of severe economic crises is directly related to the way governments, firms, and citizens react to the first signs of a possible crisis. This seems to have been understood by governments after the 2008 crisis and particularly in the context of a social crisis caused by the current COVID-19 pandemic, which in turn indicates the possibility of a recession or a more acute crisis in the global economy in the coming years. Understanding current realities requires a deeper interpretation of the lessons of the history of modern capitalism.

The dynamics of social groups in a country remain intrinsically linked to the fluctuating evolution of trust in society. Therefore, it could presumed that there is a correlation among the evolution of trust, the dynamics of social groups, and the dynamics of capitalist economies, although it is quite difficult to capture it through econometric models. To support the above statement, we selectively reviewed certain papers and assessments on the business cycle, which reflect, in fact, the dynamics of an economy.

As has been argued previously, is largely unknown as to whether and to what extent culture influences the effectiveness of political institutions in a country. In addition, the dynamics of social groups and trust can be approached from a macroeconomic and microeconomic perspective. Therefore, more extensive studies would be required for a better understanding of the relationship between social trust and the dynamics of capitalist economies.

The first major studies on the business cycle appeared around 1920, when the first signs of a possible crisis in the evolution of capitalist economies emerged. However, these studies were preceded by the investigations of Juglar, who identified a series of decennial cycles in the evolution of the American economy [44]. Subsequently, other authors have highlighted other categories of economic cycles, attempting to explain the causes that generate them and how such fluctuations could be smoothed or even prevented. For example, Kitchin, on the basis of available statistical data, identified some short economic cycles [45]. The selective review of the preeminent works on the dynamics of capitalist economies leads us to a first conclusion of interest for our study, namely, that such studies almost always ignore social factors such as trust in society, the dynamics of social groups, the quality of social capital, etc. in the major countries of the world. Partly, the situation can be explained by the fact that economic theory was somewhat dependent on rationalist approaches, but also by the difficulties inherent in the evaluation of such subjective factors.

Among these categories of economic cycles documented in the first half of the 20th century, Kondratieff's waves gained a special place in economic theory mostly because these waves can be extrapolated in connection with the real evolution of the world economy thus far (as is shown in Figure 4). Schumpeter examines in detail the interferences among Kondratieff's cycles and other categories of cycles, concluding that this is the natural form of evolution of capitalist economies, an evolution shaped by innovation and creative disruption. In his fundamental work on business cycles, Schumpeter explores in depth the fluctuating evolution of capitalist economies, including the factors 
that generate the upward phases followed by recessions/crises, but he only suggests the introduction of the concept of trustified capitalism distinctive from competitive capitalism [46].

Later, economists such as Lucas, Stiglitz, and Krugman suggested the existence of a relationship between certain "social virtues" (fair competition, honesty, ethical behavior, moral norms, etc.) and economic dynamics in capitalist economies. In fact, any economic cycle consists of an expansion phase, a peak in which the turning point occurs, and a downward phase that can manifest itself as a recession or a severe economic crisis. Despite all the studies carried out on these issues, we cannot precisely determine the moment of time at which the inflection point will appear. Moreover, although there are relevant studies on the evolution of values and prosperity over time, it is less known as to why successive changes that can generate the inflection point in the dynamics of social groups occur. We can assume, at most, that on the upward phase of an economic cycle, of Kondratieff type or other type, there is a generalized state of interpersonal trust, as well as trust in institutions, companies, systems, etc. in society. Yet, such a presumption, even if it has a logical basis, is not enough.

In Krugman's view, capitalist systems are based on certain values and institutions that should ensure the overcoming of major crises such as that of 2008 [47]. Purely speculative investments and the unethical behavior of some institutions, banks, companies, and investors, as Stiglitz argues, led to the collapse of financial markets in the United States and then globally in 2007 [48]. This idea was previously discussed by Lucas, who considered that the main cause of economic recessions would be the climate and/or the relationships between employees and millions of capitalist firms [49].

It is obvious that uncertainty, turbulence, and the chaotic business environment have become undesirable but ubiquitous "features" in capitalist society after the 2007 global crisis [50]. This state of affairs regarding the social climate has been greatly accentuated since the end of 2019 and until now because of the global pandemic, military conflicts in various regions of the world, international terrorism, cyber wars, and possible manipulations of elections, among other factors. What prospects can be outlined for the global economy in the coming years? More recent works, such as the research edited by Cristini et. al, tries to explain how the Great Recession of 2007 emerged in the USA through interpretations and developments added to existing econometric models [50]. On the one hand, some studies in this work approach the consumption behavior of American citizens and the implications of this type of behavior for a country's economic growth [50]. On the other hand, other studies explicitly aim to provide new ways of analysis and understanding of the business cycle, but suggest methodological perspectives in the same lines with classical models, even if they are based on series of longer-term statistical data [51-53]. Other authors, such as Kiani [54] or Pesce [55], offer extensive studies of the causes, manifestations, and understandings of economic cycles in developed countries but they do not deviate from the traditional perspective. Grinin et al. focused their analysis on cycles shorter than Kondratieff's, considering that disruptive technologies and policies developed by latecomers in the global economy (such as China, South Korea, and Russia) will generate cyclical evolutions of the Juglar or Kitchin type in the global economy [56]. However, they show that the evolution of world GDP, but also of the major developed economies, prove the manifestation of the first five Kondratieff waves by 2020, even if, as they point out, current studies should focus on understanding and anticipating shorter economic cycles. However, even the most recent work on this subject does not even tangentially address the relationship between the dynamics of social groups and the dynamics of capitalist economies. On the contrary, the interest of sociologists in studying the economic valences of social virtues such as trust seems more obvious. In this sense, Putnam has argued more recently the idea that the structure of social capital changes over time in all developed countries, although it is not very clear as to what the factors that forge such changes are [57]. In this context, it needs to be noted that over time sociologists are more likely to provide a well-argued descriptive model to address the dilemma of the relationship between the degree of trust in a society and the cyclical evolution of the economy in today's global environment. Along the same lines, Gorton and Tallman emphasize that capitalist societies must understand past financial crises and, on this basis, try to manage similar phenomena now or in the future [58]. The work of Gorton and Tallman shows 
how banks reacted during severe crises such as the Great Depression and the Great Recession in some countries of the world to regain citizens' trust in the banking system. This is one of the few works that suggests only a connection between the moral environment in society and the non-panic phases of an economic cycle.

The impact of the 2008 global crisis, triggered initially in the United States and expanding rapidly in the world's major countries, has become a topic of great interest to theorists, political leaders, or business decision-makers. In fact, the causes, events, and context that altogether triggered the Great Depression of 1929-1933 (involving thousands of bankruptcies, rising unemployment, lowered incomes, fear and mistrust in institutions, etc.) seem to have repeated when the global crisis broke out in 2008. The only surprise about the 2008 crisis, as Stiglitz notes, is that it took the business and political decision-makers of all capitalist states by surprise [48]. In other words, the modern capitalist state and/or the post-capitalist state seem to no longer offer certainties regarding socio-economic growth and well-being, as analysts pointed out in 1989. This was because the end of the Cold War, the fall of the Berlin Wall, and the collapse of the former Soviet empire, events that occurred in the context of the 1990s, confirmed the viability of the traditional capitalist state and the mechanism of the market economy. In other words, the Great Recession of 2008 asked question about the viability of the modern capitalist economies. The overcoming of the global crisis of 2008 in the major capitalist economies was made difficult by other related problems, such as increasing global inequalities, aging population, rising medical costs, religious conflicts, and intercontinental migration [59]. Today, the question "Does capitalism has a future?", raised by Wallerstein and other authors, has become an issue of interest to governments, central banks, corporations, and small businesses. It is not just a rhetorical question, since the hypothesis of the rehearsing of economic crises of the same magnitude cannot be excluded for the coming decades.

In the main body of economic theory, as well as in works on management, politics, or society, a particular place is granted to the Kondratieff cycles, which theoretically occur in the evolution of any capitalist economy during a period of about five decades. This category of longer cycles, also called secular cycles, was studied in greater detail by the Soviet economist N. Kondratieff in the 1920s of the last century, before the onset of the Great Depression of 1929-1933 [3]. According to Houston [60], the four waves identified by Kondratieff correspond to the events that took place in the global economy during the 20th century. Essentially, Kondratieff's study highlights the occurrence of a "wave" in the evolution of any capitalist economy for about 50 years, a period that adds up to an ascending phase of the cycle (boom) of about 25 years, followed inevitably by a downward phase of the cycle, also of about 25 years.

Moreover, according to Peter Drucker, Kondratieff's study became the most plausible explanation for the cyclical evolution of capitalist economies as the predictions made by this author were confirmed by the evolution of traditional industries in all developed capitalist economies [61]. Almost a century after the publication of Kondratieff's study, it can be said that this author anticipated both the onset of the Great Depression in 1929-1933 and the onset of the Great Recession in 2008 (noting that the latter global crisis manifested with a lag about a decade from the idealized wave of the cyclical movement).

Figure 1 summarizes the $K_{3}$ wave identified by Kondratieff and the $K_{4}$ wave extrapolating the cyclical movement in the dynamics of capitalist economies.

The idealized version of the four "waves" identified by Kondratieff for a period of about two centuries, along with K1 and K2, also includes two cycles/waves of about five decades each:

- $\mathrm{K}_{3}$ : The cycle began in 1896, reached a peak approximately in 1920, and the downward phase was recorded for about two decades until 1939.

- $\mathrm{K}_{4}$ : The ascending phase of this cycle began in 1939, continued until 1971 when it reached a peak, after which the downwards phase of the cycle followed, which was theoretically at a minimum around 1997. 


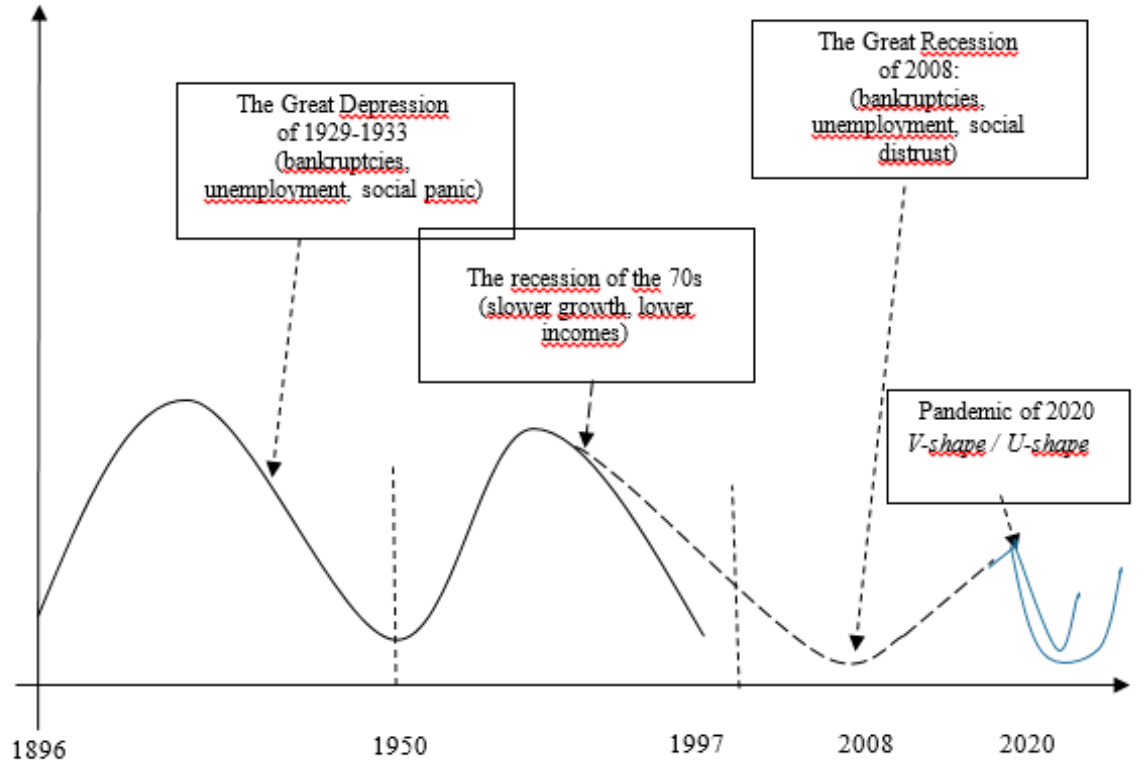

Figure 4. The $\mathrm{K}_{3}$ cycle identified by Kondratieff and the $\mathrm{K}_{4}$ cycle resulting from extrapolation. Source: Adapted from Houston [60] and Carlsson-Szlezak, Reeves, and Swartz [62].

Carlsson-Szlezak, Reeves, and Swartz [62] point out that, in the current context, the vulnerability of major world economies, including the United States, has increased as economic growth has slowed, thus becoming less able to absorb shocks. The authors of the article believe that the pandemic the world is facing today could most likely trigger a real recession (usually caused by severe economic contraction, wars, disasters, or other major disruptions). The way in which economies will succeed or avoid this recession and re-enter the path to growth will depend on a number of determinants such as the occurrence of structural distortions, the extent to which demand will be delayed, and the intensity and duration of the shock. Carlsson-Szlezak, Reeves, and Swartz [62] propose three scenarios (V-U-L) that describe the economic dynamics of the coming period. The "V-shape" scenario, which the authors consider plausible, describes the typical real recession in which, although there is an output imbalance, the annual growth rates will be able to absorb the shock. The "U-shape" scenario, also considered plausible, is a worse version of the V scenario, in which the shock persists and, although the initial growth is resumed, permanent output losses occur. Finally, the "L-shape" scenario is considered the most pessimistic, but also the least plausible; according to this projection, radical structural changes and serious dysfunctions in the labor market, in capital formation, or in productivity could occur in most economies. Major previous outbreaks, such as Spanish flu (1918), Asian flu (1958), Hong Kong flu (1968), and SARS (2002), had a V-shape evolution.

Reflecting in retrospect on the transformations that previous crises, regardless of their causes and nature, have induced, we should point out that changes are expected to occur in many spheres of economic and social life. First, at the microeconomic level, it is possible to reconfigure business models; increase interest in innovation; and introduce new technologies, new approaches in human resources management, etc. A classic example is how Alibaba quickly adapted to the context of the 2003 SARS epidemic and introduced online commerce in China, later becoming one of the most powerful global companies [63]. At the macroeconomic and world level, we expect to witness a reanalysis of the motivations that determine the outsourcing of operations and the internationalization of business, given the syncopations that appeared in the global value chains after the outbreak of the current pandemic in China at the beginning of 2020. It is the social dimension that is likely to experience a consistent decline in institutional and systemic confidence because of the manner in which national institutions and international organizations have responded and managed the crisis. From our point of view, the magnitude of this depreciation of trust can modify the above-mentioned scenarios and add new pressure points on the economic evolution in the next period. In other words, as recently 
emphasized Klaus Schwab, the current global pandemic is a "litmus test" for modern stakeholder capitalism [64].

It is noteworthy that the predictions made by Kondratieff a century ago remain the best explanation for the dynamics of capitalist economies [61-65]. After 2008, however, it has been evident that an atypical manifestation of Kondratieff's "waves" have emerged due to the public policies applied by the major governments of the world, disruptive technologies, and other factors. In addition, for the first time in the last two centuries, we can see on the horizon a possible "minimum" of Kondratieff's waves induced not by an economic cause (a stock market crash, as happened in 1929 and 2008) but by an exclusively social cause, namely, the emergence, first of all, of a social crisis (distrust and fear caused, in turn, by a global pandemic affecting millions of people, etc.).

\subsection{Social Trust and Business Cycle in the Context of the Latest Economic Recessions}

In the first decades of the 20th century, the more or less orderly alternation between good times and worse periods characterized the business environment [66]. The interest in this cyclicality that described the business environment was consistently reflected in a vast body of literature. Nowadays, the deeper interdependence in the world economy, globalization, and technology have become sources of a synchronized fragility that can generate change at any time [67]. This idea entered the horizon of theoretical reflection during the 1960s, mainly through the work of Peter Drucker. The Age of Discontinuity [68] is an exposition of an era of global discontinuity, shaped by transformations in technology, economic policies, industrial structures, economic theory, the knowledge needed to govern and manage, as well as and in economic problems. Later, in The New Realities, Drucker [69] describes a new economic habitat, namely, the transnational world economy, with a concrete existence, but that which is very different from that of the national economies and, at the same time, with a significant influence on them. In this habitat, the accentuated dynamics of change throw economies, especially those that are technologically developed, into a state of progeria and, at the same time, bear an economy described by Toffler [70] as an economy of impermanence or of ephemerality. "... Change accelerates and complexities multiply", as Toffler notes, anticipating a profound reconfiguration of the economic system [70]. This economic system, the economic system of the third wave, is highly volatile and confusing; is full of risks and tension; and is marked by spasms and convulsions, shortages, and chaotic surpluses of energies and resources of the rapid change of consumers', workers', and managers' attitudes, trade imbalances, and factors [71].

The anticipations of Drucker and Toffler have become true sources of inspiration; words such as chaos and turbulent environment have appeared frequently in the description of the business environment since the 1980s [72-74]. Today, more and more opinions are converging on the belief that turbulence, with its obvious consequences in chaos, risk, and uncertainty, has become the new normality in the global business environment [67]. Industries, markets, and companies are facing increased vulnerability, but also an avalanche of opportunities born out of this new normality. Turbulence, Kotler and Caslione note, is the new normality, interrupted by periodic and intermittent outbreaks of prosperity and decline-including prolonged periods of recession/depression [67].

In a book dedicated to the profound changes that have occurred in the business environment specific to the post-crisis context, Kotler and Caslione [67] explore a number of factors whose concerted action has generated a new kind of turbulence that is described by the term chaotics. In what follows, the main chaos- and turbulence-generating factors in the post-crisis business environment are summarized.

- Factor F1: The information revolution

The Internet, telecommunications, and digitalization provide almost unlimited access to information/knowledge for all individuals and organizations, which means access to the main resource to compete globally. The Internet, e-commerce, and online communications are for the modern 
society a technological instrument just as important as the railways for the entire Western civilization since 1830 [73].

- Factor F2: Disruptive innovations

The technological developments of the last two and a half centuries have ensured a clear dominance of the West over other civilizations as they have led to increased productivity and economic growth, as well as increasing funds invested in research, education, continuous innovation, and other similar features of modern society. The term disruptive technology was coined by Bower and Christensen in a paper published in the Harvard Business Review [75]. Later, Christensen and Raynor replaced the term disruptive technology with disruptive innovation [76]. The idea per se is not an absolute novelty because eight decades ago Schumpeter $[77,78]$ discussed the radical innovations and "creative disruption" that new technologies bring.

- Factor F3: Ascension of the "rest of the world"

The financial crises of the 2000s actually accentuated a process that started about two decades earlier, namely, the redistribution of power in the global economy, as China, the new industrialized countries of Asia, and the wealthy countries of the Middle East began to assert themselves as emerging economies. The BRICS group of countries tended to improve its relative position in the global economy, especially after 2010, when China became the world's second largest economy, which could mean a loss of power/influence held by the United States and Europe. The phrase "ascension of the rest of the world" belongs to Zakaria [79], who shows that, after a century of the United States dominating the global economy, China and other emerging powers are already a distinct pole of economic power.

- Factor F4: Hyper-competition

Disruptive innovations, IT, the knowledge revolution, and the new "actors" in different markets together generate new driving forces of globalization and lead to an unprecedented increase in competition between large multinational corporations in different markets. In addition, smaller companies in Western economies and the so-called "latecomer" firms in the global economy, which can produce some goods/services at lower cost conditions, develop internationalization strategies and capture market segments traditionally held by large corporations [80].

- Factor F5: The environment

Over the last four decades, more and more pressure has been exerted on all categories of companies so that each one can define a certain code of conduct, especially with regard to environmental protection, consumer protection, and the use of certain categories of technologies. Such pressures have been and are being exercised by international bodies, governments, the media, as well as by the public in Western countries. International conventions, as well as the legislation enforced by the national governments regarding the protection of the environment and the need to use green technologies [81-83], obviously create constraints and opportunities for companies.

- $\quad$ Factor F6: Customer ability

As the Internet, social networks, and e-commerce expand, consumers around the world have many sources of information, documentation, and choice about certain goods or services. Consumers can already make precise demands on a particular product and choose among different variants of distribution, which requires transparency and ethical behavior of companies. 
- Factor F7: Sovereign funds and other current factors

According to Kotler and Caslione [67], funds from China, Singapore, Abu Dhabi, and Kuwait reached assets of about USD 4 billion in 2008, investing in corporations listed on Wall Street or major stock exchanges in Europe. The huge liquidities available to these investments funds and their aggressive strategy over the past decades have led to some fears from Western governments as countries are struggling to protect certain industries or strategic sectors. "Other current factors" include the emergence of social crises generated by various factors and with influence at global, regional, national, or local levels; factors such as military conflicts such as those in Syria; political conflicts; international terrorism; cyber warfare; pandemics such as the current one; etc.

The last decades have been marked by a visible tendency towards risk diversification and a significant increase in the destructive potential of risks, which has led some analysts to advance the paradigm of a "risk society" [84,85]; they appreciate that in advanced modernity the production of wealth is systematically accompanied by a "production" of risks. The most recent report of the World Economic Forum on Global Risks [86] shows that vulnerable societies aggravate macroeconomic risk factors. Concern for inequality is at the root of social unrest on almost all continents, although it may have different sources, such as corruption, failure to comply with laws, or rising prices for basic goods and services. However, on average, inequality at a global level has decreased, yet at the national level, inequalities have increased, especially in developed countries, wherein they have sometimes reached historical levels.

These trends, accompanied by the increasingly discussed idea of growth limits [87-89], have asked many questions about the idea of prosperity as a continuous expansion of material well-being. Beliefs that seemed unreal a few decades ago are now subject to analysis from other perspectives. The old paradigms seem to have exhausted the possibilities of answering the questions raised by new contexts. Tim Jackson [90] launched a fundamental question in the landscape of sustainability issues, namely, what does prosperity mean in a world modeled by social and ecological limits? He points out that modern Western society was in a social crisis long before the 2008 economic crisis broke out, a crisis manifested, inter alia, by the disintegration of communities and a loss of social trust. One of the conclusions reached is that mainspring of prosperity is the sense of belonging and trust in the community; prosperity transcends the material dimension, integrating the strengths of social relations and trust.

Since the 1920s, the theory of economic cycles has embraced the role of psychological factors in economic behavior in terms of amplifying or shortening the phases of cycles. The economic downturns of recent decades imposed the need to reconsider the standard approaches, which no longer provide sufficiently well-articulated answers to the new realities and characteristics of business cycles, especially in capitalist economies. The specificities of the global business environment, previously described as chaotics, transform the mechanisms and factors of propagation of shocks in the economy, among which are manifested the socio-cultural components that include social trust.

As Stiglitz remarked, referring to the 2007 crisis, it "sprang from a catastrophic collapse in confidence" and "the crisis in trust extends beyond banks. In the global context, there is a dwindling confidence in US policy makers" [91]. However, the literature does not yet provide robust arguments and evidence in this direction.

In Table 2, the most relevant contributions to the study of the relationship between social trust and business cycle or economic crisis are summarized [92-96]. 
Table 2. Synopsis of the main contributions exploring the relationship between social trust and business cycle or economic crisis in the context of the latest economic recessions.

\begin{tabular}{|c|c|c|c|c|}
\hline \multirow{2}{*}{$\begin{array}{c}\text { Author } \\
\text { (Publication Year) }\end{array}$} & \multirow{2}{*}{$\begin{array}{l}\text { Rationale/Aim of } \\
\text { the Research }\end{array}$} & \multicolumn{2}{|c|}{ Methodology } & \multirow{2}{*}{$\begin{array}{c}\text { Main } \\
\text { Findings/Results }\end{array}$} \\
\hline & & Design/Perspectives & Data/Sample & \\
\hline \multirow{2}{*}{$\begin{array}{l}\text { Stevenson and } \\
\text { Wolfers (2011) }\end{array}$} & \multirow{2}{*}{$\begin{array}{l}\text { Explores the link } \\
\text { between the Great } \\
\text { Recession (2007) } \\
\text { and the high level } \\
\text { of distrust in U.S. } \\
\text { public institutions. }\end{array}$} & \multirow{2}{*}{$\begin{array}{c}\text { Time series analysis } \\
\text { (macroeconomic } \\
\text { view) }\end{array}$} & $\begin{array}{l}\text { National trends } \\
\text { Gallup Trust in } \\
\text { Institutions Data } \\
\text { (1972-2010) } \\
\text { General Social } \\
\text { Survey, Confidence } \\
\text { in Institutions } \\
\text { (1972-2008) } \\
\text { Gallup Trust and } \\
\text { Honesty Data } \\
\text { (1976-2010) } \\
\text { Time trend of } \\
\text { unemployment } \\
\text { rate }\end{array}$ & $\begin{array}{l}\text { Public confidence } \\
\text { in each of the } \\
\text { selected } \\
\text { institutions } \\
\text { included (U.S. } \\
\text { Congress, banks } \\
\text { and financial } \\
\text { institutions, major } \\
\text { companies, U.S. } \\
\text { Supreme Court, the } \\
\text { press) is } \\
\text { pro-cyclical. }\end{array}$ \\
\hline & & & $\begin{array}{l}\text { International } \\
\text { comparison } \\
\text { The Gallup World } \\
\text { Poll } \\
\text { Pre- crisis } \\
\text { observation } \\
\text { (2006-2007) } \\
\text { Post- crisis } \\
\text { observation } \\
\text { (2009-2010) } \\
\text { Time trend of } \\
\text { unemployment } \\
\text { rate } \\
65 \text { to } 71 \text { countries }\end{array}$ & $\begin{array}{l}\text { The existence of a } \\
\text { close link between } \\
\text { macroeconomic } \\
\text { conditions and } \\
\text { trust, especially } \\
\text { with regard to } \\
\text { financial } \\
\text { institutions and } \\
\text { national } \\
\text { governments. }\end{array}$ \\
\hline $\begin{array}{l}\text { Coibion et al. } \\
\text { (2013) }\end{array}$ & $\begin{array}{l}\text { Assesses possible } \\
\text { explanations for } \\
\text { the persistence of } \\
\text { unemployment in } \\
\text { the United States } \\
\text { since the 1980s (the } \\
\text { last three } \\
\text { recessions) and its } \\
\text { increasing } \\
\text { long-term } \\
\text { cyclicality. }\end{array}$ & $\begin{array}{c}\text { Time series } \\
\text { analysis } \\
\text { (macroeconomic } \\
\text { view) }\end{array}$ & $\begin{array}{l}14 \text { countries } \\
(1970-2011)\end{array}$ & $\begin{array}{l}\text { The changes in the } \\
\text { mechanisms of } \\
\text { shock propagation } \\
\text { in the economy, } \\
\text { one of the factors } \\
\text { being the decline of } \\
\text { social trust, } \\
\text { influencing the } \\
\text { increasingly } \\
\text { persistent } \\
\text { unemployment, } \\
\text { but also the change } \\
\text { in other features of } \\
\text { the business cycle. }\end{array}$ \\
\hline
\end{tabular}


Table 2. Cont.

\begin{tabular}{|c|c|c|c|c|}
\hline \multirow{2}{*}{$\begin{array}{c}\text { Author } \\
\text { (Publication Year) }\end{array}$} & \multirow{2}{*}{$\begin{array}{l}\text { Rationale/Aim of } \\
\text { the Research }\end{array}$} & \multicolumn{2}{|c|}{ Methodology } & \multirow{2}{*}{$\begin{array}{c}\text { Main } \\
\text { Findings/Results }\end{array}$} \\
\hline & & Design/Perspectives & Data/Sample & \\
\hline Díaz et al. (2015) & $\begin{array}{l}\text { Examines how the } \\
\text { political situation } \\
\text { (which includes the } \\
\text { trust in public } \\
\text { institutions } \\
\text { component) has } \\
\text { changed with the } \\
\text { business cycle in } \\
\text { Spain over the last } \\
20 \text { years. } \\
\text { Investigates the } \\
\text { existence of a } \\
\text { long-term } \\
\text { relationship } \\
\text { between the } \\
\text { unemployment } \\
\text { rate (as a variable } \\
\text { that correlates } \\
\text { negatively with } \\
\text { GDP and } \\
\text { approximates the } \\
\text { effects of the } \\
\text { business cycle) and } \\
\text { the political } \\
\text { situation. }\end{array}$ & $\begin{array}{c}\text { Time series } \\
\text { analysis } \\
\text { (macroeconomic } \\
\text { view) }\end{array}$ & $\begin{array}{l}\text { Quarterly data on } \\
\text { unemployment } \\
\text { rate in Spain } \\
\text { (1992-2012) } \\
\text { Political } \\
\text { Situation-CIS } \\
\text { Survey (Centro de } \\
\text { Investigaciones } \\
\text { Sociológicas, } \\
\text { 1992-2012) } \\
\text { (strongly correlated } \\
\text { with political trust } \\
\text { in the period } \\
\text { 1996-2012 in Spain) }\end{array}$ & $\begin{array}{l}\text { The level of the } \\
\text { unemployment } \\
\text { rate has led to a } \\
\text { significant change } \\
\text { in the political } \\
\text { situation in Spain. } \\
\text { Statistical } \\
\text { arguments } \\
\text { supporting the } \\
\text { hypothesis of the } \\
\text { pro-cyclicality of } \\
\text { the political } \\
\text { situation in Spain. } \\
\text { A model that } \\
\text { allows the } \\
\text { quantitative } \\
\text { evaluation of the } \\
\text { business cycle } \\
\text { impact on the } \\
\text { political situation. }\end{array}$ \\
\hline Bilan et al. (2019) & $\begin{array}{l}\text { Outlines a } \\
\text { theoretical } \\
\text { framework that } \\
\text { tries to explain the } \\
\text { causal mechanism } \\
\text { between financial } \\
\text { cycles and business } \\
\text { cycles through the } \\
\text { trust component } \\
\text { (with its roots in } \\
\text { the institutional } \\
\text { economics } \\
\text { approach). } \\
\text { Explores the } \\
\text { pro-cyclical nature } \\
\text { of trust and } \\
\text { synchronization } \\
\text { with financial } \\
\text { cycles } \\
\text { and business } \\
\text { cycles. }\end{array}$ & $\begin{array}{c}\text { Empirical analysis } \\
\text { (macroeconomic } \\
\text { view) }\end{array}$ & $\begin{array}{l}\text { OECD Indicators of } \\
\text { macroeconomic } \\
\text { development } \\
\text { Consumer } \\
\text { Confidence Index } \\
\text { Business } \\
\text { Confidence Index } \\
\text { EU 28, USA, } \\
\text { Ukraine } \\
\text { (post-crisis period) }\end{array}$ & $\begin{array}{l}\text { Descriptive } \\
\text { theoretical model } \\
\text { of the trust cycle } \\
\text { that explores the } \\
\text { correlation } \\
\text { between financial } \\
\text { fluctuations, } \\
\text { changes in the level } \\
\text { of trust, and broad } \\
\text { fluctuations of } \\
\text { business cycles. } \\
\text { The level of trust is } \\
\text { a pro-cyclical } \\
\text { indicator that } \\
\text { manifests itself } \\
\text { before a country's } \\
\text { economic growth. } \\
\text { There is a cycle of } \\
\text { trust that } \\
\text { determines the } \\
\text { economic cycle } \\
\text { with a certain delay. } \\
\text { The widespread } \\
\text { trust from financial } \\
\text { systems to } \\
\text { economic systems } \\
\text { in general leads to } \\
\text { economic crises. }\end{array}$ \\
\hline
\end{tabular}


Table 2. Cont.

\begin{tabular}{|c|c|c|c|c|}
\hline \multirow{2}{*}{$\begin{array}{c}\text { Author } \\
\text { (Publication Year) }\end{array}$} & \multirow{2}{*}{$\begin{array}{l}\text { Rationale/Aim of } \\
\text { the Research }\end{array}$} & \multicolumn{2}{|c|}{ Methodology } & \multirow{2}{*}{$\begin{array}{c}\text { Main } \\
\text { Findings/Results }\end{array}$} \\
\hline & & Design/Perspectives & Data/Sample & \\
\hline $\begin{array}{l}\text { Liu and Dong } \\
\qquad(2020)\end{array}$ & $\begin{array}{l}\text { Analyzes the } \\
\text { impact of EPU } \\
\text { (Economic Policy } \\
\text { Uncertainty) on } \\
\text { trade credit, taking } \\
\text { into account the } \\
\text { active role of social } \\
\text { trust. }\end{array}$ & $\begin{array}{l}\text { Fixed effects model } \\
\text { (microeconomic } \\
\text { view) }\end{array}$ & $\begin{array}{l}\text { Panel data } \\
\text { (quarterly } \\
\text { firm-level data) } \\
4000 \text { firms } \\
16 \text { economies } \\
\text { 1995Q1-2015Q1 }\end{array}$ & $\begin{array}{l}\text { Social trust } \\
\text { strengthens the } \\
\text { positive effect of } \\
\text { EPU. } \\
\text { Firms offer less } \\
\text { trade credit to their } \\
\text { customers after the } \\
\text { increase in EPU. } \\
\text { Under EPU } \\
\text { conditions, firms in } \\
\text { regions with a } \\
\text { higher level of } \\
\text { social trust offer } \\
\text { more commercial } \\
\text { credit than similar } \\
\text { firms in regions } \\
\text { with a lower level } \\
\text { of social trust. }\end{array}$ \\
\hline
\end{tabular}

Beyond the extremely small number of papers exploring the influences between social trust and business cycle, we must stress that the macroeconomic perspective of analyzing these influences prevails. While this research perspective may lead to important conclusions, we believe that the assumption of a negative correlation between the unemployment rate and the evolution of the GDP becomes questionable in the context of innovation and technological advancement, which have become essential characteristics of the contemporary business environment.

\section{Discussion and Implications}

The study of the relationship between trust and the cyclical evolution of capitalist economies remains, by its very nature, a subject scarcely addressed in the literature on economics, sociology, or management. Typically, theorists have endeavored to understand over time the relatively more visible causes or factors that generate the fluctuating evolution of capitalist economies so that, on this basis, ways/tools for managing this phenomenon can be proposed later. Most of the studies on this subject concern the macroeconomic perspective, since at this level there are empirical data that allow for highlighting the ascending and declining phases, as done by Kondratieff. From a macroeconomic perspective, the most frequently mentioned causes in theory regarding the phenomenon of cyclicality are the cyclical evolution of the innovative processes, the monetary policies developed by the central banks, the electoral cycles, the influence of some natural factors on human behavior, etc.

It is common knowledge that China's development and its expansion in the global economy, especially after 2010, cannot be fully explained by the same traditional economic theories that explain the expansion of Western capitalist systems. A series of recent studies has indicated that the Western capitalist system has also brought distrust, fear, and uncertainty to millions of citizens, even in developed countries [5]. How can we explain such current realities? As Padua clarifies, some social virtues, such as the reputation of a person or institution, interpersonal trust, and honest behavior, influence the behavior of economic actors, even if such virtues are harder to capture and analyze through econometric models. Thinking about the social realities that came with the 2007 crisis in the United States, two important questions formulated by Padua must be reiterated: Why social trust collapses in the context of a crisis? and How can trust be regained? She discusses an article published in 1937 by Keynes [97] in which he notes that capitalist economies are characterized by a fluctuation of 
the social climate and that this climate is shaped by the trust, hope, fear, and courage of millions of participants in the market.

Certain realities of the global economy in recent years support the basic idea of our study. Thus, phenomena such as migration flows, international terrorism, and the current global pandemic seem to have led to a cumulative social effect in early 2020. All the assessments made by the World Bank, International Monetary Fund, European Union, etc. in the spring of 2020 anticipated a new recession or even a crisis in all developed economies of the world. Most Western governments have reacted quickly and preventively to these signs of economic crisis by allocating more than USD 1 trillion as financial support packages. As has been mentioned above, it can be assumed that the governments of developed economies drew some conclusions from the lessons of the Great Depression of the 1930s and the Great Recession of 2007. Paradoxically, although there were credible signs of a recession or even a crisis in the global economy, stock markets in the United States, Europe, and Asia have remained stable or have even recorded increases of the main indexes. It is presumable that the preventive attitude of governments keeps an acceptable level of trust in financial markets and in the behavior of shareholders and investors, with this trust then spreading among the public.

Estimates made in August 2020 anticipate a dramatic decline in the GDP of the world's major economies this year, while economic developments in 2021 are still uncertain. It is the first time in the history of capitalism since the Industrial Revolution that there are prospects for a severe recession and yet the financial markets remain stable. One explanation could be found in the evolution of social trust. Gorton and Tallman consider that the panic that characterized the previous recessions in the history of capitalism seems to no longer occur for reasons related to investment, protecting the economies of the population, the eventual bankruptcy of some banks, etc. [58]. On the contrary, the economies of the population tend to grow in the major countries, precisely as a measure of individual protection of citizens against the consequences of a possible economic crisis. This situation emerged in correlation with the attitude of governments that publicly announced other support measures for companies and the population, which also influenced the status of social trust.

Perhaps paradoxically, the market value of some multinational companies continued to grow significantly during the period of 2019-2020. For example, the market value of Apple exceeded USD 2 trillion, with this being the first company in the USA, but also in the world, to exceed this threshold. Another example is ARAMCO in Saudi Arabia, which operates in the oil industry and is a company with a market value of more than USD 1.7 trillion, given that, amid the global pandemic and reduced consumption in China as the largest importer of oil, the price of oil has dropped to a value that can be considered "symbolic". The explanation is rooted, at least in part, in the evolution of social trust in the main countries of the world. It is largely unknown as to how the scores of social capital in international rankings will evolve during the year 2020, both overall and on various components, but it is quite clear that some forms of trust, i.e., trust in institutions and trust in the system, remain stable in the major developed countries. The same cannot be said about interpersonal trust, whichseems to weaken in these countries, but here the explanations refer mainly to extra-economic factors.

Along the same flow of argument drawn by Padua, it is noteworthy that an in-depth analysis of Keynes's conceptions of institutional trust and systemic trust would provide pertinent answers to questions that concern not only governments, but also companies and common citizens. In the economic and political context that followed World War I, Keynes argued for the need to build trust among the governments of the former belligerent parties, although at those time this view was labeled only as excessive idealism.

From the perspective of this study, it is worth noting that trust can be a social factor that is harder to quantify and to introduce into theoretical models, but it mediates the relationship between various disturbing factors of the social environment and the behavior of social groups. In other words, it is important to highlight that various economic, political, monetary, technological, and other factors that manifest at the level of a country/nation gradually change the existing state of trust in the society and, subsequently, the behavior of the social group and the performance in terms of economic growth. 
It is appropriate to conduct a more in-depth exploration of the relationship that could be potentially seen between the social trust and the economic growth at the country level at two relatively distinct moments in time, namely:

- for the first part of the 20th century, going as far as 1997, the moment predicted by Kondratieff at which the minimum of a period of global recession or crisis should have occurred (this moment was offset by about a decade by the main European countries and the USA, especially through monetary policies, but it was very profound in the Asian countries);

- for the period from 2008 to the present, this being from the moment at which the global economic crisis began, involving the seven factors of chaoticism that were described in Section 3.3.

As is well known, there is no comprehensive empirical model that can accurately predict the moment when the turning point will occur in the manifestation of an economic cycle on the basis of the evolution of the main macroeconomic indicators. This is because part of the behavior and dynamics of social groups cannot be modeled in any objective way.

Figure 5 shows the possible relationship between trust and the cyclical evolution of the economy, in the traditional view that preceded the onset of the crisis of 2008.

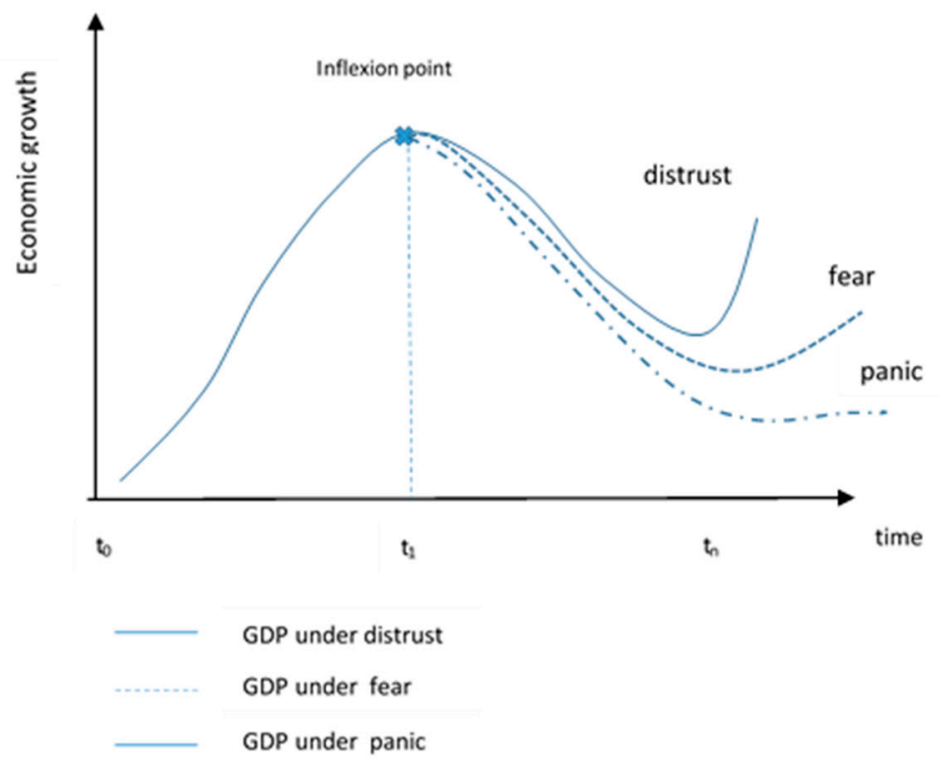

Figure 5. Descriptive model of trust and business cycle: the traditional approach (until 2008).

In the "natural" evolution of an economy, the maximum point will be reached at a time $t_{1}$; however, if signs of a loss of trust appear, inflection is expected to occur earlier. Figure 6 sketches the relationship between trust and economic dynamics in the context of the turbulent/chaotic economic environment (modeled by the seven factors described in Section 3.3). Integrating the issues discussed above, it must be stated that, in the context of a turbulent environment, the breach or even the lack of trust will influence the moment of peak and the form and amplitude of the economic cycle, with panic being the factor that could shape the most pessimistic scenario, i.e., an L-shape. 


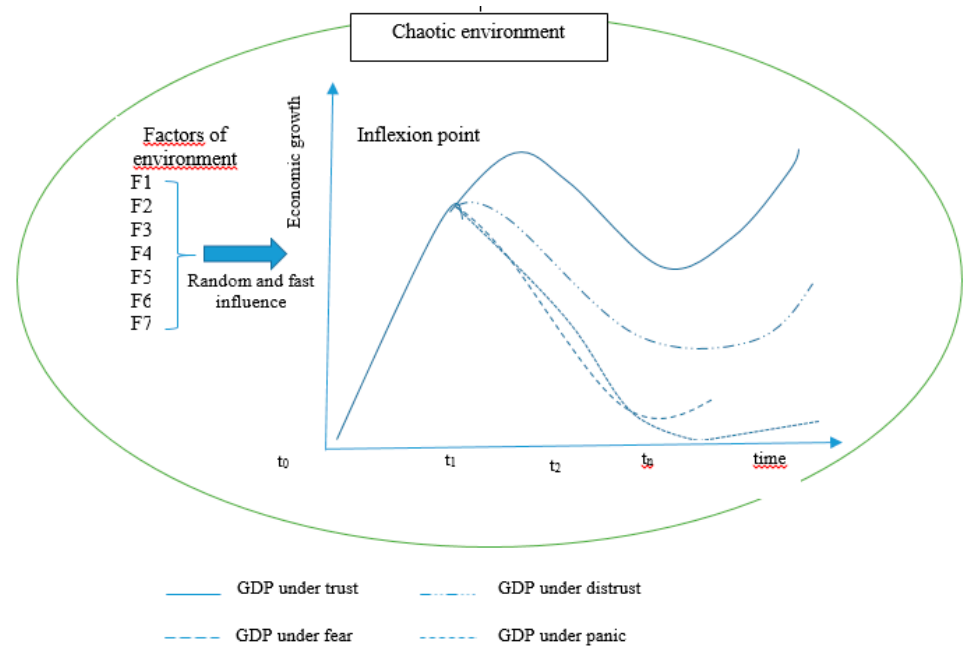

Figure 6. Descriptive model of trust and business cycle in a chaotic environment (since 2008).

From 2008 until now, the policies and/or strategies developed by the main countries of the world have been based, in essence, on the idea supported by Kondratieff's studies/waves. Such recent orientations in the policy of Western governments have become essential for promoting sustainable development and will be emphasized in the coming decades. This is because all traditional industries have closely followed the Kondratieff's waves and economic crises are influencing the income distribution and are expected to exacerbate poverty, thus affecting the progress towards sustainable development goals. In this context, the sustainable development strategies developed by countries require trust, support, and participation of millions of people. Any sustainable development scenario must increasingly take into account the economic valences of the social dimension of life, implicitly of social trust and their influences on the patterns of evolution of business organizations, but also of national economies.

At the micro level, the relationship between trust and sustainable economic performance is relatively different from what it could be noticed and highlighted from a macroeconomic perspective. This is because, even in the upward phase of Kondratieff or other shorter cycles, there clearly are bankruptcies, reorganizations, and a certain mobility of the workforce, which gives greater stability to the relationship between the individual and the group.

When, for whatever reason, the economic performance of a company reaches a turning point compared to previous years and enters a downward trend, it is up to the owners to change the CEO and his/her team and, on this basis, gradually induce a climate of trust between employees and the organization. There is still a big question mark regarding the interest of companies towards social factors, which, together with other factors (economic, political, technological, etc.) shape the environment in which they operate and want to gain profit and a better position in the market.

\section{Concluding Thoughts}

This paper discusses a novel view of the relationship between social and economic dimensions of life by summarizing and integrating two of the main groundbreaking and inspirational streams of thought—social trust and economic dynamics.

The paper extends the area of knowledge by summarizing and integrating the conceptual paradigm of social trust and the dynamics of capitalist economies. Subsequently, this paper contributes to the literature by offering an image of the scientific landscape shaped by the concept of social trust; it points out the main directions of research in this area and explores a relatively new scientific niche.

Our insights aim to open some analysis and reflection directions for policy makers, opinion leaders, managers, top executives from large corporations, bankers, and investors, as well as researchers in economics, sociology, etc. It is known that political decision-makers are particularly concerned only 
with short-term results (a four-year election cycle) and often ignore the "lessons" that history generously offers. The consequence of a factual state of the type invoked is intrinsically linked with economic, social, or other costs that are then paid by millions of individuals. There are several conclusions to be drawn from our scientific endeavor, some of which are discussed below.

First, it is foreseeable that other global/regional economic crises will occur in the decades to come as a confirmation of Kondratieff's atypical manifestations of the "waves". It had to be acknowledged that we cannot formulate sufficiently well-grounded predictions about the magnitude of such economic crises, their recession forms, their country-specific manifestation, etc.

Second, the studies of authors such as Weber, Porter, Putnam, Fukuyama, or Drucker provide an extremely valuable conceptual framework for understanding the importance of trust and values in shaping the economic behavior of individuals. However, further studies, approaches, and conceptualizations are needed in order to enhance the knowledge of the values in which the individual of the post-capitalist society believes, which motivates individuals to form various groups, which are the advantages of belonging to a network of individuals and/or companies, which is the relationship between disruptive technologies and the dynamics of social groups, etc. When Weber suggested a possible relationship between religion and the prosperity of a country, he was in fact wrong, as the post-war history of the global economy shows. However, it is indisputable that only through education can the values of the "other" be acknowledged, can trusting relationships with the "other" be built, and can the essential principles or the essential social norms under which we can claim the exercise of a set of individual freedoms be achieved.

Third, not enough is known about how and/or to what extent political institutions, religion, or technical networks (created by the Internet, telecommunications, satellites, etc.) participate in developing and maintaining a valuable social capital in a country/nation-a social capital based on trust and ethical behavior of individuals and/or organizations.

Instead, it is significant that factors of the type F1-F7 described in the previous sections could generate, individually or cumulatively, a real chaos in the current socio-economic environment (this environment offers threats and opportunities for companies and countries). It is also known that distrust or even fear can suddenly arise in the behavior of a large social group; how this trust is regained depends essentially on how the government, the central banks, and other institutions of the capitalist state react when the first signs of crisis and/or distrust appear.

Somewhat paradoxically, the modern capitalist state has become more necessary and more "social" than it has been at any other historical moment in the last three centuries. This is because today the state is the first to respond when a crisis of any kind occurs and to draw a clear direction for millions of people to try to rebuild their social trust in the shortest possible time.

This novel level of understanding can support more rigorous studies whose results could be of utmost importance for business organizations in addressing the problem of business sustainability, but also for economic decision-makers. In addition, several other research questions could be very challenging: Do the constraints imposed by sustainable development change the historical patterns of economic cycles? Which types of business cycles are more vulnerable to panic and distrust? Does social trust flatten or "preserve" the historical pattern of economic cycles?

Author Contributions: Conceptualization, A.B., R.K., and I.B.; methodology, A.B., R.K., and I.B.; software, A.B., R.K., and I.B.; validation, A.B., R.K., and I.B.; formal analysis, A.B., R.K., and I.B.; investigation, A.B., R.K., and I.B.; resources, A.B., R.K., and I.B.; data curation, A.B., R.K., and I.B.; writing-original draft preparation, A.B., R.K., and I.B.; writing-review and editing, A.B., R.K., and I.B.; visualization, A.B., R.K., and I.B.; supervision, A.B., R.K., and I.B.; project administration, A.B., R.K., and I.B.; funding acquisition, A.B., R.K., and I.B. All authors have read and agreed to the published version of the manuscript.

Funding: This research received no external funding.

Conflicts of Interest: The authors declare no conflict of interest. 


\section{References}

1. Weber, M. Etica Protestantă și Spiritul Capitalismului; Antet: Bucharest, Romania, 2003.

2. Durkheim, E. Formele Elementare ale Vieții Religioase; Polirom: Iași, Romania, 1995.

3. Kondratieff, N. The Major Economic Cycle, 1925. In Long Wave Cycle; E.P. Dutton: Boston, MA, USA, 1984.

4. Keynes, J.M. The General Theory of Employment, Interest, and Money; Harcourt, Brace \& World: New York, NY, USA, 1936.

5. Padua, D. John Maynard Keynes and the Economy of Trust the Relevance of the Keynesian Social Thought in a Global Society; Palgrave Macmillan US: New York, NY, USA, 2014.

6. Deutsch, M. Trust and Suspicion. J. Confl. Resolut. 1958, 2, 265-279. [CrossRef]

7. Rotter, J.B. A new scale for the measurement of interpersonal trust. J. Personal. 1967, 35, 651-665. [CrossRef] [PubMed]

8. Luhmann, N. Trust and Power; John Wiley \& Sons, Inc.: Chichester, UK, 1979.

9. Zucker, L. Production of Trust: Institutional Sources of Economic Structure, 1840-1920. Available online: /paper/ Production-of-trust\%3A-Institutional-sources-of-Zucker/b3816479d1e3b33c6960062d9b34ee08b80bfe98 (accessed on 2 September 2020).

10. Putnam, R.D.; Leonardi, R.; Nanetti, R. Making Democracy Work: Civic Traditions in Modern Italy; Princeton University Press: Princeton, NJ, USA, 1993; ISBN 978-0-691-07889-2.

11. Hofstede, G.; Hofstede, G.J.; Minkov, M. Cultures and Organizations: Software of the Mind; Intercultural Cooperation and its Importance for Survival, 3rd ed.; McGraw-Hill: New York, NY, USA, 2010; ISBN 978-0-07-177015-6.

12. Inglehart, R.F. Cultural Evolution: People's Motivations Are Changing, and Reshaping the World, 1st ed.; Cambridge University Press: Cambridge, UK, 2018; ISBN 978-1-108-61388-0.

13. Huntington, S.P.; Harrison, L.E. Culture Matters: How Values Shape Human Progress; Huntington, S.P., Harrison, L.E., Eds.; Basic Books: New York, NY, USA, 2000; ISBN 978-0-465-03175-7.

14. Fukuyama, F. Social Capital. The Tanner Lectures on Human Values; Brasenose College: Oxford, UK, 1997.

15. Fukuyama, F. Trust: The Social Virtues and the Creation of Prosperity; The Free Press: New York, NY, USA, 1995.

16. Herreros, F. Political evolution and institutional change. In The Problem of Forming Social Capital: Why Trust? 1st ed.; Palgrave Macmillan: New York, NY, USA, 2004; ISBN 978-1-4039-6482-3.

17. Putnam, R.D. Bowling Alone; Simon \& Schuster: New York, NY, USA, 2000.

18. Avram, E.; Shockley-Zalabak, P. Trust: The Bedrock of Individual and Organizational Excellence; Editura Universitară: Bucharest, Romania, 2008.

19. Giddens, A. The Consequences of Modernity; Polity Press: Cambridge, UK, 2008; ISBN 978-0-7456-0923-2.

20. Uslaner, E.M. The Oxford Handbook of Social and Political Trust; Uslaner, E.M., Ed.; Oxford University Press: New York, NY, USA, 2018; ISBN 978-0-19-027480-1.

21. Coleman, J.S. Social Capital in the Creation of Human Capital. Am. J. Sociol. 1988, 94, S95-S120. [CrossRef]

22. Burciu, A.; Prelipcean, G.; Bostan, I.; Hapenciuc, V.; Chaşovschi, C.; Roman, C.; Popescu, M.; Vancea, R.; Dîmbu, D.; Năstase, C. Introducere in Management; Burciu, A., Ed.; Editura Economică: Bucharest, Romania, 2008.

23. Tester, K. Panic; Routledge: New York, NY, USA, 2013; ISBN 978-1-136-22147-7.

24. Rothstein, B.; Uslaner, E.M. All for All: Equality, Corruption, and Social Trust. World Pol. 2005, 58, 41-72. [CrossRef]

25. Bergh, A.; Bjørnskov, C. Trust, welfare states and income equality: Sorting out the causality. Eur. J. Political Econ. 2014, 35, 183-199. [CrossRef]

26. Bostan, I.; Grosu, V. The social effects of the current economic crisis on the European Union labor market. Rev. Cercet. Interv. Soc. 2010, 31, 7-21.

27. Morariu, A. The management of the human resources in the public health system: The complexity and the euro-global socio-economic challenges. Rev. Cercet. Interv. Soc. 2014, 44, 266-278.

28. Morariu, A. Labour Productivity: Concept and Tendencies. Ovidius Univ. Ann. Econ. Sci. Ser. 2017, 17, 258-262.

29. Asalos, N.; Vasile, I. Conceptual Aspects and a New Vision of Competitiveness in Actual Economic Context. Ovidius Univ. Ann. Econ. Sci. Ser. 2015, 15, 439-443.

30. Asalos, N.; Georgescu, C.E. Aspects and interactions of competitiveness and efficiency in context of a durable development. Case study on touristic sector. Rev. Econ. 2011, 4, 7-10. 
31. Lazar, C.M. Organizational Performance and Substantiate Organizations Work Mainly on Intangible Resources. Ovidius Univ. Ann. Econ. Sci. Ser. 2012, 12, 568-571.

32. Lazăr, C. The Knowledge Stage of Economy based on Knowledge. Ovidius Univ. Ann. Econ. Sci. Ser. 2011, 11, 692-695.

33. Brooks, C.; Manza, J. Studies in communication, media, and public opinion. In Why Welfare States Persist: The Importance of Public Opinion in Democracies; University of Chicago Press: Chicago, IL, USA, 2007; ISBN 978-0-226-07583-9.

34. Dotti Sani, G.M.; Magistro, B. Increasingly unequal? The economic crisis, social inequalities and trust in the European Parliament in 20 European countries: Increasingly unequal? Eur. J. Political Res. 2016, 55, 246-264. [CrossRef]

35. Torrente, D.; Bolancé, C.; Cais, J. Economic Crisis and Social Trust: Reviewing the Effects of Economic Hardship on Interpersonal and Institutional Confidence. SSRN J. 2018. [CrossRef]

36. Bolancé, C.; Caïs, J.; Torrente, D. Trust in Times of Economic Crisis in Spain: Paradoxes for Social Capital Theory; Working Papers 2018; IREA: Barcelona, Spain, 2018.

37. Anton, S.; Bostan, I. The Role of Access to Finance in Explaining Cross-National Variation in ntrepreneurial Activity: A Panel Data Approach. Sustainability 2017, 9, 1947. [CrossRef]

38. Porter, M. On Competition; Harvard Business Review Press: Boston, MA, USA, 2008.

39. Porter, M.E.; Kramer, M.R. The Big Idea: Creating Shared Value. Harv. Bus. Rev. 2011, 89, 62-77.

40. Inglehart, R.; Welzel, C. Changing Mass Priorities: The Link between Modernization and Democracy. Perspect. Politics 2010, 8, 551-567. [CrossRef]

41. Legatum Institute Foundation. The Legatum Prosperity Index 2019; Legatum Institute Foundation: London, UK, 2019.

42. Galbraith, J.K. The Great Crash of 1929; Mariner Books: Boston, MA, USA; Houghton Mifflin Harcourt: Boston, MA, USA, 2009.

43. Robbins, L. Essay on the Nature and Significance of Economic Science; MacMillan and Co, Limited: London, UK, 1932.

44. Juglar, C. Des Crises Commerciales et de Leur Retour Périodique; Nouvelle édition [en ligne]; ENS Éditions: Lyon, France, 2014; ISBN 9782847885774. Available online: http://books.openedition.org/enseditions/1382 (accessed on 13 October 2020). [CrossRef]

45. Kitchin, J. Cycles and Trends in Economic Factors. Rev. Econ. Stat. 1923, 5, 10-16. [CrossRef]

46. Schumpeter, J. Business Cycles A theoretical, Historical and Statistical Analysis of the Capitalist Process; McGraw Hill Book Company: New York, NY, USA, 1939.

47. Krugman, P.R. The Return of Depression Economics and the Crisis of 2008; Norton: New York, NY, USA, 2009; ISBN 978-0-393-07101-6.

48. Stiglitz, J. Freefall: America, Free Markets, and the Sinking of the World Economy; W.W. Norton \& Company: New York, NY, USA, 2010.

49. Lucas, R.E. Models of Business Cycles; Basil Blackwell: Oxford, UK, 1987.

50. Fazzari, S.M.; Greenberg, E. Are macreconomic models with ceilings and floors useful in understanding the Great Recession? In Cycles, Growth and the Great Recession; Routledge: Abingdon, UK, 2014; pp. 45-65, ISBN 978-1-315-79663-5.

51. Salanti, A. The theory of business cycle from a methodological perspective. In Cycles, Growth and the Great Recession; Routledge: Abingdon, UK, 2014; pp. 66-74, ISBN 978-1-315-79663-5.

52. Toporowski, J. The business cycle as a method of analysis. In Cycles, Growth and the Great Recession; Routledge: Abingdon, UK, 2014; pp. 77-83, ISBN 978-1-315-79663-5.

53. Vercelli, A. The asymmetric-information approach and the Great Recession. In Cycles, Growth and the Great Recession; Routledge: Abingdon, UK, 2014; pp. 84-100, ISBN 978-1-315-79663-5.

54. Kiani, K.M. Business Cycle Fluctuations and Economic Policy; Nova Science Publishers, Inc.: New York, NY, USA, 2009.

55. Pesce, A. Contributions to Economics. In Economic Cycles in Emerging and Advanced Countries; Springer International Publishing: Cham, Switzerland, 2015; ISBN 978-3-319-17084-8.

56. Grinin, L.; Korotayev, A.; Tausch, A. Economic Cycles, Crises, and the Global Periphery; Springer International Publishing: Cham, Switzerland, 2016; ISBN 978-3-319-41260-3.

57. Putnam, R. Democracies in Flux: The Evolution of Social Capital in Contemporary Society; Putnam, R., Ed.; Oxford University Press: New York, NY, USA, 2003; Volume 40. 
58. Gorton, G.B.; Tallman, E.W. Fighting Financial Crises: Learning from the Past; University of Chicago Press: Chicago, IL, USA, 2018; ISBN 978-0-226-47951-4.

59. Wallerstein, I.; Collins, R.; Mann, M.; Derluguian, G.; Calhoun, C. Does Capitalism Have a Future? 1st ed.; Oxford University Press: New York, NY, USA, 2013; ISBN 978-0-19-933085-0.

60. Houston, W. Riding the Business Cycle; Little Brown and Company: London, UK, 1996; ISBN 978-0-7515-1618-0.

61. Drucker, P.F. The Essential Drucker: Selections from the Management Works of Peter F. Drucker; PerfectBound: New York, NY, USA, 2001; ISBN 978-0-06-001054-6.

62. Carlsson-Szlezak, P.; Reeves, M.; Swartz, P. What Coronavirus Could Mean for the Global Economy. Harvard Business Review, 3 March 2020; H1-H10.

63. Lowrey, Y. The Alibaba Way: Unleashing Grassroots Entrepreneurship to Build the World's Most Innovative Internet Company, 1st ed.; The global business thought leader series; McGraw-Hill Education: New York, NY, USA, 2016; ISBN 978-1-259-58541-8.

64. Schwab, K. Covid-19 Is a Litmus Test for Stakeholder Capitalism. Available online: https://www.ft.com/ content/234d8fd6-6e29-11ea-89df-41bea055720b (accessed on 26 March 2020).

65. Drucker, P.F. Innovation and Entrepreneurship; Harper Business: New York, NY, USA, 2006; ISBN 978-0-06-085113-2.

66. Von Mises, L. The Causes of the Economic Crisis: And other Essays before and after the Great Depression; Ludwig von Mises Institute: Auburn, AL, USA, 2006; ISBN 978-1-933550-03-9.

67. Kotler, P.; Caslione, J.A. Chaotics: The Business of Managing and Marketing in the Age of Turbulence; AMACOM: New York, NY, USA, 2009; ISBN 978-0-8144-1521-4. (In Romanian)

68. Drucker, P.F. The Age of Discontinuity. Guidelines to Our Changing Society; Heinemann: London, UK, 1969.

69. Drucker, P.F. Realitatile Lumii de Maine; Teora: Bucharest, Romania, 1999.

70. Toffler, A. Socul Viitorului; Editura Politică: Bucharest, Romania, 1973.

71. Toffler, A. Al Treilea Val; Editura Politică: Bucharest, Romania, 1983.

72. Drucker, P.F. The Frontiers of Management; Routledge: New York, NY, USA, 2011.

73. Drucker, P. Managing in the Next Society; Griffin: New York, NY, USA, 2003; ISBN 978-0-312-32011-9.

74. Sanders, T.I. Strategic Thinking and the New Science: Planning in the Midst of Chaos Complexity and Change, 1st ed.; Free Press: New York, NY, USA, 1998; ISBN 978-0-684-84268-4.

75. Bower, J.L.; Christensen, C.M. Disruptive Technologies: Catching the Wave; Harvard Business Review: Brighton, UK, 1995; H43-H53.

76. Christensen, C.M.; Raynor, M.E. The Innovator's Solution: Creating and Sustaining Successful Growth, 1st ed.; Harvard Business Review Press: Boston, MA, USA, 2013; ISBN 978-1-4221-9657-1.

77. Schumpeter, J.A. Capitalism, Socialism, and Democracy; Social Science Research Network: Rochester, NY, USA, 1942.

78. Schumpeter, J.A. Capitalism, Socialism, and Democracy, 3rd ed.; Harper Perennial Modern Classics: New York, NY, USA, 2008; ISBN 978-0-06-156161-0.

79. Zakaria, F. The Post-American World, 1st ed.; W.W. Norton \& Company: New York, NY, USA, 2008; ISBN 978-0-393-06235-9.

80. Storper, M.; Thomadakis, S.; Tsipouri, L. Latecomers in the Global Economy; Taylor \& Francis: Abingdon, UK, 1998; ISBN 978-0-203-97924-2.

81. Bostan, I.; Burciu, A.; Condrea, P. Trends of the communitarian cohesion policies and advertising for eco-investments. Environ. Eng. Manag. J. 2010, 9, 847-851.

82. Mates, D.; Grosu, V.; Hlaciuc, E.; Bostan, I.; Bunget, O.; Domil, A.; Moraru, M.; Artene, A. Biological assets and the agricultural products in the context of the implementation of the IAS 41: A case study of the Romanian agro-food system. Arch. Biol. Sci. 2015, 67, 705-714. [CrossRef]

83. Bostan, I.; Burciu, A.; Condrea, P.P.; Durac, G. Involvement of legal responsibility for severe acts of pollution and noncompliance. Environ. Eng. Manag. J. 2009, 8, 469-473.

84. Adam, B.; Beck, U.; van Loon, J. The Risk Society and Beyond: Critical Issues for Social Theory; SAGE Publications Ltd.: London, UK, 2000; ISBN 978-0-7619-6469-8.

85. Beck, U. World at Risk; Polity Press: Cambridge, UK, 2009.

86. Granados Franco, E. The Global Risk Report 2020; World Economic Forum: Geneva, Switzerland, 2020.

87. Meadows, D.H.; Meadows, D.L.; Randers, J. Beyond the Limits: Confronting Global Collapse, Envisioning a Sustainable Future; Chelsea Green Publishing Co.: White River Junction, VT, USA, 1992; ISBN 978-0-930031-55-8. 
88. Meadows, D.H.; Meadows, D.L.; Randers, J.; Behrens, W.E.W., III. The Limits to Growth; Universe Books: New York, NY, USA, 1972.

89. Meadows, D.H.; Randers, J.; Meadows, D.L. The Limits to Growth: The 30-Year Update; Earthscan: London, UK, 2009; ISBN 978-1-84407-144-9.

90. Jackson, T. Prosperity without Growth. Foundations for the Economy of Tomorrow, 2nd ed.; Routledge: London, UK; New York, NY, USA, 2017.

91. Joseph Stiglitz: The Financial Crisis Is the Fruit of Dishonesty on the Part of Financial Institutions. Available online: http://www.theguardian.com/commentisfree/2008/sep/16/economics.wallstreet (accessed on 30 August 2020).

92. Stevenson, B.; Wolfers, J. Trust in Public Institutions over the Business Cycle. Am. Econ. Rev. 2011, 101, 281-287. [CrossRef]

93. Coibion, O.; Gorodnichenko, Y.; Koustas, D. Amerisclerosis? The Puzzle of Rising U.S. Unemployment Persistence; NBER: Cambridge, MA, USA, 2013.

94. Álvarez-Díaz, M.; Caballero, G.; Manzano, B.; Martín-Moreno, J.M. Assessment of Political Situation over the Business Cycle in Spain: A Time Series Analysis. Rev. Public Econ. 2015, 213, 41-62.

95. Bilan, Y.; Brychko, M.; Buriak, A.; Vasilyeva, T. Financial, business and trust cycles: The issues of synchronization. Zb. Rad. Ekon. Fak. Rij. 2019, 37, 113-138. [CrossRef]

96. Liu, P.; Dong, D. Impact of Economic Policy Uncertainty on Trade Credit Provision: The Role of Social Trust. Sustainability 2020, 12, 1601. [CrossRef]

97. Keynes, J.M. The general theory of employment. Q. J. Econ. 1937, 51, 209-223. [CrossRef]

Publisher's Note: MDPI stays neutral with regard to jurisdictional claims in published maps and institutional affiliations. 